\title{
THE KONDAROS-KATSIMOUTI INTERMEDIATE- SULFIDATION EPITHERMAL PB-ZN-AG-MN MINERALIZATION, WESTERN MILOS, GREECE: NEW MINERALOGICAL AND GEOCHEMICAL DATA
}

\author{
Papavasiliou K. ${ }^{1}$, Voudouris P. ${ }^{2}$, Kanellopoulos C. ${ }^{3}$, Alfieris D. ${ }^{4}$ and Xydous \\ S. ${ }^{2}$ \\ ${ }^{1}$ Faculty of Geology and Geoenvironment, University of Athens, Department of Economic Geology \\ \& Geochemistry, Panepistimiopolis A. Ilisia 15784 Athens/Greece, papavas@geol.uoa.gr \\ ${ }^{2}$ Faculty of Geology and Geoenvironment, University of Athens, Department of Petrology, \\ Panepistimiopolis A. Ilisia15784 Athens/Greece,voudouris@geol.uoa.gr,stxydous@geol.uoa.gr \\ ${ }^{3}$ Institute of Geology and Mineral Exploration, $1^{\text {st }}$ Spirou Louis St., Olympic Village, 13677, \\ Acharnae, Greece, ckanellopoulos@gmail.com \\ ${ }^{4}$ Imerys Filtration, 15A Metaxa Street, Kifisia 14564, Greece,Dimitris.Alfieris@imerys.com
}

\begin{abstract}
The metallic mineralization in Kontaros-Katsimouti area is an epithermal $\mathrm{Pb}-\mathrm{Zn}-\mathrm{Ag}$ mineralization located along the NW-trending Kondaros-Katsimouti-Vani fault, NW Milos Island, Greece. It is hosted within propylitically and argillically altered dacitic flow dome and volcaniclastic sandstone and shows features typical of intermediate sulfidation deposits like colloform banding, cockade breccias and gangue adularia, Mnrich carbonates and amethystine quartz. The Kondaros-Katsimouti system evolves at higher elevation into the Vani Ag-Pb mineralization, which occurs proximal to the Vani manganese deposit. The metallic mineralogical assemblage at Kondaros-Katsimouti includes mainly galena and sphalerite and minor pyrite. Silver is present in the form of Ag- $(C d)$-rich tetrahedrite (up to $23.1 \mathrm{wt}$. \% Ag) and polybasite included in galena. Bulk ore analyses indicate enrichment in W (up to $424 \mathrm{mg} / \mathrm{kg}$ ) and Mo (up to $24 \mathrm{mg} / \mathrm{kg}$ ), similarly to the other neighboring mineralizations in western Milos (e.g. Vani, TriadesGalana). This enrichment suggests a magmatic-hydrothermal contribution to the ore fluids, probably from a buried granitoid at depth. Boiling, in addition to mixing processes between magmatic- and seawater, resulted in $\mathrm{pH}$ increase, oxidation and temperature decrease, and resulted into ore deposition.

Keywords: Silver sulfosalts, tungsten, epithermal, boiling-mixing, Milos island.
\end{abstract}

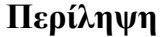

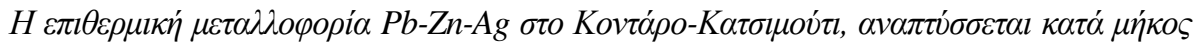

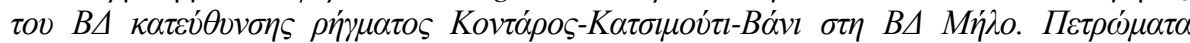

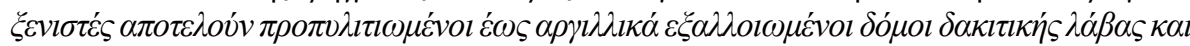

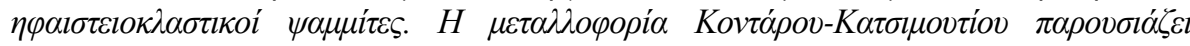

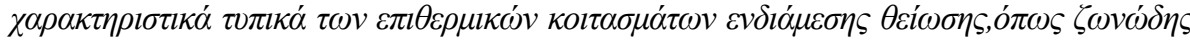

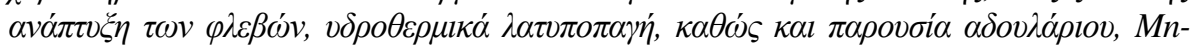

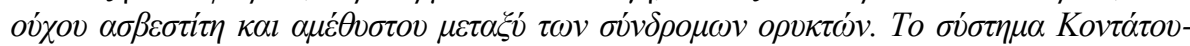




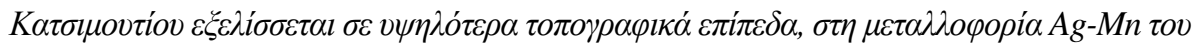

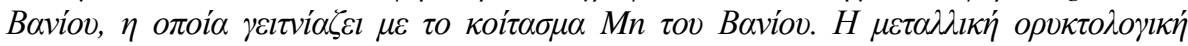

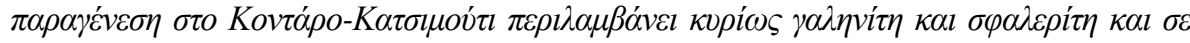

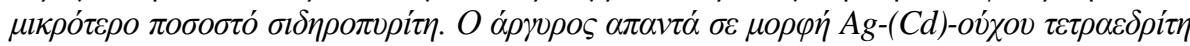

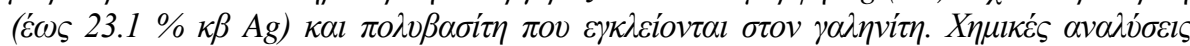

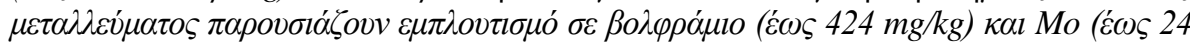

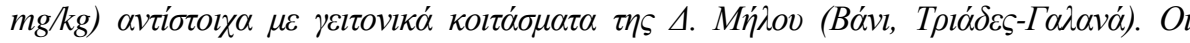

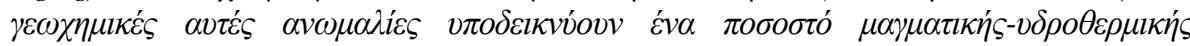

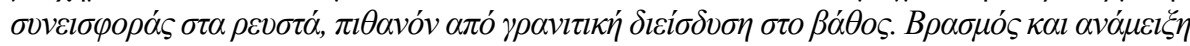

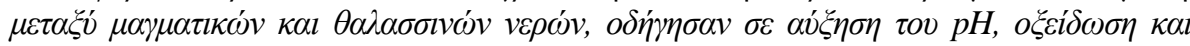

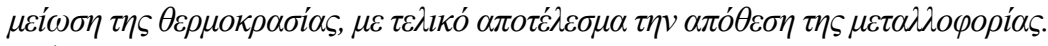

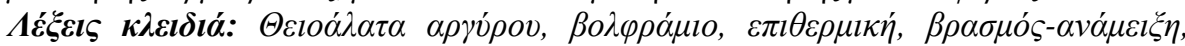

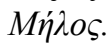

\section{Introduction}

Milos Island is one of the most densely mineralized areas in Greece, characterized by epithermal $\mathrm{Au}-\mathrm{Ag}$ and base metal deposition within a Plio-Pleistocene volcanic edifice. Metallic mineralization on western Milos was the subject of several mineralogical and geochemical studies, with base- and precious metal mineralization having been classified as either Kuroko- (Hauck, 1988; Vavelidis and Melfos, 1998), seawater-dominated epithermal (Kilias et al., 2001; Liakopoulos et al., 2001; Marchik et al., 2010), shallow submarine epithermal- (Alfieris, 2006; Stewart and McPhie, 2006; Alfieris et al., 2013), or hybrid volcanogenic massive sulfide (VMS)-epithermal types (Naden et al., 2005). A modern analogue for the setting of epithermal-style mineralization in western Milos is the shallow submarine Kolumbo hydrothermal vent field located $7 \mathrm{~km} \mathrm{NE}$ of Santorini Island in the Hellenic arc (Kilias et al., 2013). Along the NW-trending Kondaros-Katsimouti fault a base metal and Ag-bearing epithermal mineralization was found (Alfieris and Voudouris, 2005). This veinsystem extends NW towards Cape Vani, and includes the Kondaros-Katsimouti $\mathrm{Pb}-\mathrm{Zn}-\mathrm{Ag} \pm \mathrm{Cu} \pm \mathrm{Mn}$ intermediate-sulfidation epithermal system (Alfieris and Voudouris, 2005) and the Vani Ag-Pb epithermal prospect, which is proximal to the Vani manganese deposit, and is highly enriched in Ag-bearing phases (e.g. native silver, argentite/acanthite, silver halides, argentian covellite) (Voudouris et al., 2014). Already Alfieris and Voudouris (2005) suggested that epithermal banded quartz-chalcedony-barite-Mn-Fe veins at Katsimoutis represent feeder zones to the Vani stratiform Mn-Ba-Pb-Zn mineralization, described by Hein et al. (2000), Liakopoulos et al. (2001) and Glasby et al. (2005). Under this respect the Kondaros-Vani fault, played a major role in the formation of the Vani manganese deposit, since manganese deposition represents the final hydrothermal manifestation of the major $\mathrm{Pb}-\mathrm{Zn}$-Ag epithermal system. The latter also represents the sub-seafloor feeder zones of the stratiform $\mathrm{Mn}-\mathrm{Ba}-\mathrm{Pb}-\mathrm{Zn}$ deposit that formed on the sea floor at Cape Vani (Alfieris and Voudouris, 2005).

The aim of the current study is to present new data on the metallic mineralization at KontarosKatsimouti area, to describe its mineralogical and geochemical characteristics and discuss the role of various physico-chemical mechanisms in its formation by comparing it with other mineralized areas in western Milos and elsewhere.

\section{Geological setting and mineralization}

Milos Island forms part of the Cycladic Blueschist in the Attico-Cycladic massif, a polymetamorphic terrane within the Alpine orogen of the Hellenides (Jolivet and Brun, 2010; Papanikolaou, 1987; Ring et al., 2010). Miocene extension in the Aegean Sea was accompanied by the intrusion and extrusion of magmatic rocks at upper crustal levels (Altherr and Siebel, 2002). Milos is located in the central part of the Lower Pliocene to Recent South Aegean Active Volcanic Arc, which includes a belt of calc-alkaline volcanic centers (Sousaki, Aegina, Methana, Poros, Milos, Santorini, Kos, 
and Nisyros) consisting mainly of basalts, andesites, dacites, and rhyolites (Fytikas et al., 1986). It comprises mainly Neogene sediments and volcanic rocks overlying a metamorphic basement that consists of eclogites, glaucophane schists and mica schists (Fytikas et al., 1986; Stewart and McPhie, 2006; Fig. 1). The Upper Miocene to Lower Pliocene sedimentary sequence contains basal conglomerates, shallow marine carbonates and sandstones from the base to top with minor intercalations of tuffs, and is succeeded by volcanic rocks that can be subdivided into four main phases from Middle to Upper Pliocene (3.5 Ma) to Pleistocene (0.08 Ma) (Alfieris et al., 2013; Fytikas et al., 1986; Stewart and McPhie, 2006): The earliest volcanic episode (Middle to Upper Pliocene, 3.5-3.0 Ma) produced a succession of felsic submarine units including pumice flows, tuffs and pumice rich pyroclastic flows, with locally intrusive subvolcanic bodies, lavas and/or hyaloclastites. Some volcanosedimentary products have been deposited in E-W directed graben structures from 3.0 to $2.7 \mathrm{Ma}$. The subsequent phase of submarine volcanism (Upper PlioceneLower Pleistocene, 2.7-1.4 Ma) is characterized by the emplacement of dacitic/andesitic domes, plugs and lava flows along a system of mainly NE-trending faults, and subordinately along NW-SE to E-W directions. These domes intruded and disrupted the still unconsolidated volcanosedimentary unit, suggesting contemporaneous emplacement in a shallow seawater environment. Hyaloclastitic margins around a flow banded coherent core and talus breccias characterize the subvolcanic emplacement of this volcanic rock into sediments. Based on SHRIMP U-Pb in zircon, Stewart and McPhie (2006) dated submarine dacite lavas at $2.18 \pm 0.09$ Ma and submarine to subaerial daciticrhyodacitic flow banded domes and their autobreccias at $1.44 \pm 0.08 \mathrm{Ma}$ (both at Triades). The effusive activity was accompanied locally by explosive episodes, which locally produced bedded pumiceous tuff cones and/or pyroclastic flows and breccias in submarine and partially subaerial environments. During Lower to Middle Pleistocene (1.4-0.5 Ma), intense shallow marine to subaerial pyroclastic activity associated with rhyolitic domes and lavas was developed in the eastern and northeastern part of the island.

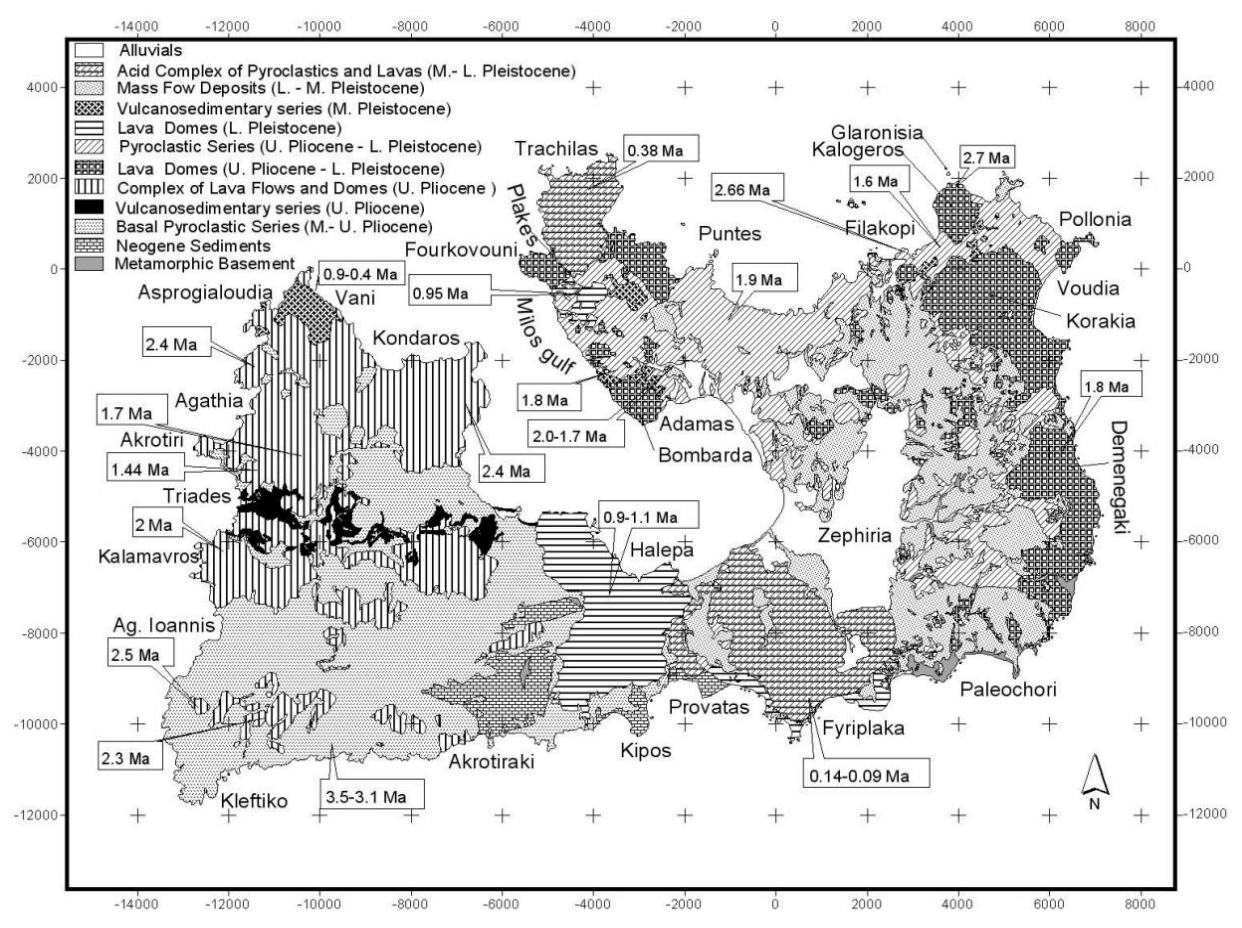

Figure 1 - Geological map of Milos Island showing the distribution of the main volcanic phases, metamorphic and sedimentary units, as well as geochronological data (after Fytikas et al., 1986; Alfieris, 2006). 
The most recent volcanic activity on Milos is concentrated along the eastern coast of Milos gulf, where there are felsic centres with ages of 0.38-0.08 Ma (Middle-Upper Pleistocene). At Milos Island, Miocene to Pliocene extensional tectonics resulted in four main fault sets trending NW, N, $\mathrm{NE}$, and $\mathrm{E}$.

The studied metallic mineralization is located along the NW-trending Kondaros-Katsimouti fault. The mineralization is hosted within propylitically and argillically altered dacitic flow dome and volcaniclastic sandstone and shows features typical of intermediate sulfidation deposits, like colloform banding and cockade breccias (Fig. 2a-c). The mineralized system consists of banded veins (up to $1 \mathrm{~m}$ thick and up to $100 \mathrm{~m}$ length) and stockworks, including alternating bands of quartzchalcedony with galena, sphalerite and minor pyrite, hematite, chalcopyrite and silver-bearing sulfosalts (e.g. tetrahedrite and polybasite) (Fig. 2 and Table 1). Quartz, calcite, Mn-rich calcite, barite and adularia (e.g. sanidine) are the gangue minerals (Table 1).

\section{Materials and methods}

Fourty five thin- and polished-sections of the sulfide mineralization were prepared from eight samples of Kondaros-Katsimouti area: KO1A, KO1B, KO2, KA1, KA2 and KA3 along the NWtrending fault and KA4 and KA4Q located within the NE-trending Triades-Galana-Katsimouti fault. $\mathrm{KO} 1$ and $\mathrm{KO} 2$ represent a hydrothermal breccia composed of milky and amethystine quartz fragments within a matrix of sulfides, carbonates and barite. KA1 consists of epithermal vein material showing initial deposition of sulfides plus minor barite (KA1A) followed by colloform banded chalcedony, aragonite and hydrothermal manganese oxides (KA1B). KA2 represent epithermal vein composed of sulfides and barite cross cutting propylitized lavas as in KA1 but without the final stage of deposition of hydrothermal manganese oxides. KA3 is epithermal veinmaterial of manganese oxides, aragonite and minor barite cross cutting propylitized lavas. Finally, KA4 and KA4Q are quartz veins enriched in pyrite, galena, sphalerite and minor chalcopyrite.

The samples were studied by optical microscopy and a JEOL JSM 5600 scanning electron microscope, equipped with back-scattered imaging capabilities, at the Department of Mineralogy and Petrology, University of Athens. The chemical compositions of sulfides and sulfosalts were determined with a JEOL JSM 5600 scanning electron microscope, equipped with an automated energy dispersive analysis system ISIS 300 OXFORD, with the following operating conditions: accelerating voltage $20 \mathrm{kV}$, beam current $0.5 \mathrm{nA}$, time of measurement $50 \mathrm{~s}$ and beam diameter $1-2 \mathrm{~mm}$. The spectra were processed using ZAF software. The mineralogical composition of the samples was also investigated through powder X-ray diffraction (XRD). The XRD study was carried out using a Siemens Model 5005 X-ray diffractometer in combination with the DIFFRAC plus software package. The diffractometer was operated using $\mathrm{CuK} \alpha$ radiation at $40 \mathrm{kV}$ and $40 \mathrm{~mA}$ and employing the following scanning parameters: step size $0.020^{\circ}$ and step time from 1.0 to $20.0 \mathrm{sec}$. The raw files (XRD diagrams) were evaluated with the EVA 10.0 software (Table 1).

Table 1. Semi-quantitative (XRD) mineralogical estimation of the samples from Kondaros (KO) and Katsimouti (KA) area.

Mineral abundances: $* * * * *=$ dominant $; * * *=$ abundant $; * *$ common $; * *=$ minor $; *=$ rare.

\begin{tabular}{|c|c|c|c|c|c|c|c|c|c|}
\hline & Barite & Sanidine & Quartz & Sphalerite & Galena & Pyrite & Calcite & Mn-calcite & Hematite \\
\hline KA-1A & $* *$ & $* *$ & & $* * * * *$ & $* * *$ & $*$ & $* * * *$ & $* * * *$ & \\
\hline KA-1B & & & $*$ & & & & $* * * * *$ & $* * * * *$ & $* *$ \\
\hline KA-2 & $* * *$ & & $* * *$ & $* * * * *$ & $* * *$ & $* *$ & $* * * *$ & $*$ & \\
\hline KA-3 & & & & & & & $* * * * *$ & $* * * * *$ & \\
\hline KA-4 & & & $* * * * *$ & $* * *$ & $*$ & $*$ & & & $*$ \\
\hline KA-4Q & & & $* * * * *$ & $* * *$ & $*$ & $*$ & & & $*$ \\
\hline KO-1 & $*$ & $* *$ & $* * *$ & $* * * *$ & $* * * * *$ & $* *$ & $* * *$ & $* *$ & \\
\hline KO-2 & $* *$ & $*$ & $* * * * *$ & $* * *$ & $* *$ & & & & \\
\hline
\end{tabular}



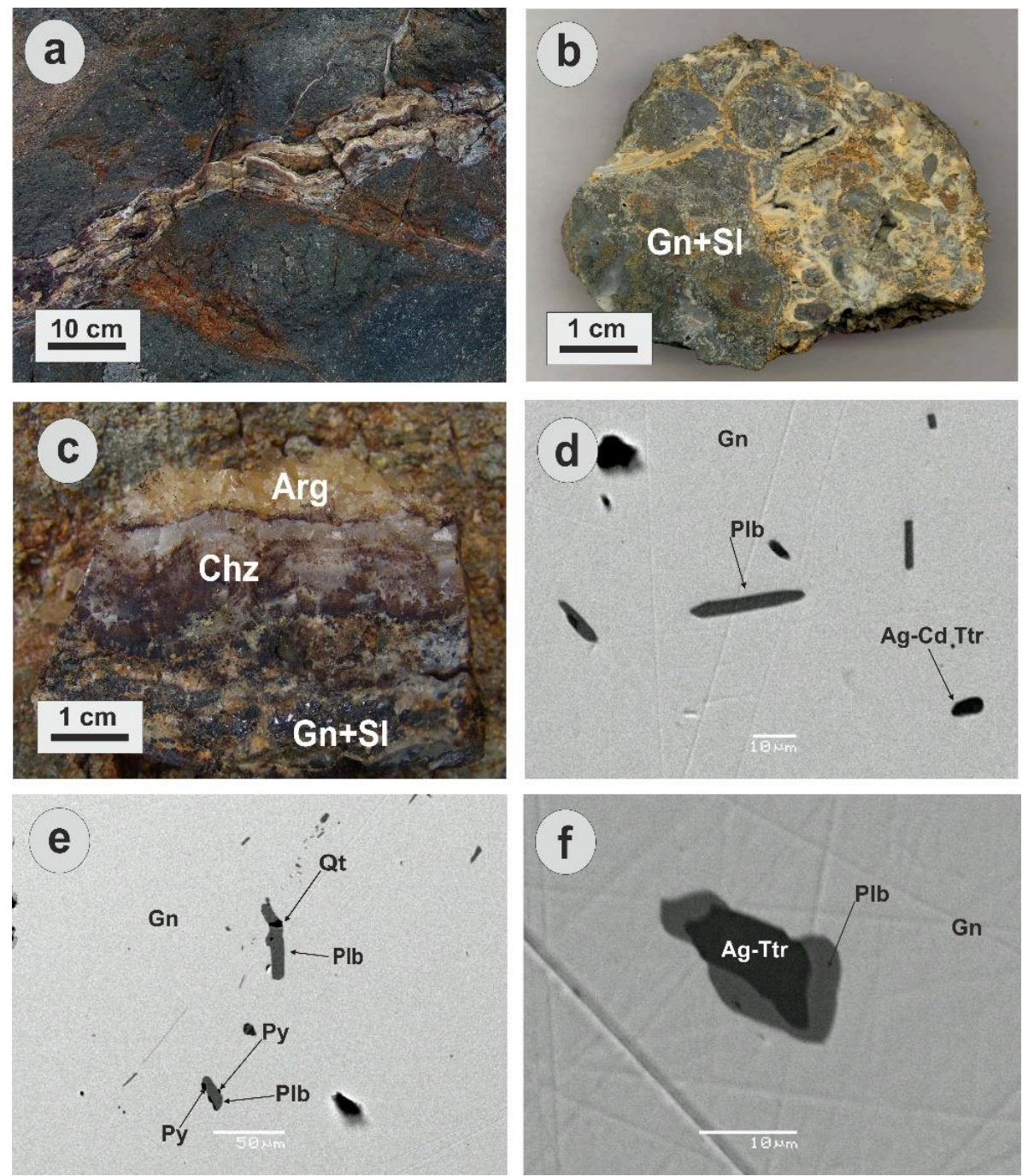

Figure 2 - Macroscopic photographs (a to c) and (d to f) SEM-BSE images demonstrating ore assemblages at Kontaros-Katsimouti metallic mineralization: (a) colloform-banded quartzchalcedony-sulfide vein crosscutting propylitic altered dacite, (b) hand specimen of cockade breccia with subangular galena-sphalerite (Gn-Sl) fragments, surrounded by aragonite, (c) banded vein, with early deposition of Galena-sphalerite, followed by chalcedony (Chz) and then by aragonite (Arg), (d) polybasite (Plb) and Ag-Cd-rich tetrahedrite (Ag-Cd-Ttr) included in galena (Gn), (e) polybasite, pyrite (Py) and quartz (Qt) included in galena, (f) Agrich tetrahedrite (Ag-Ttr) surrounded by polybasite and included in galena.

Part of the samples were also digested with a mixture of $\mathrm{HClO}_{4}-\mathrm{HNO}_{3}-\mathrm{HF}$ acids and were analyzed for a series of trace elements using Inductively Coupled Plasma-Atomic Emission Spectrometry (ICP-AES) and Inductively Coupled Plasma-Atomic Emission Spectroscopy (ICP-MS) and a series of major elements by Inductively Coupled Plasma-Optical Emission Spectrometry (ICP-OES) at the Department of Chemistry, University of Gottingen, Germany. 


\section{Analytical results}

\subsection{Sulfide-sulfosalt mineralogy and mineral chemistry}

Representative microanalyses of metallic mineral phases are presented in Table 2 and all data of the Ag-bearing sulfosalts are plotted in Figure 3. The metallic mineral phases at Kontaros-Katsimouti area show the following characteristics:

Galena is major constituent of the metallic mineralization assemblage of Kondaros-Katsimouti (Fig. 2). Galena is the main host of Ag-sulfosalts, which usually appear as inclusions. Paragenetic relations suggest contemporaneous deposition of galena with sphalerite (Fig. 2b, c). The Ag, Bi and $\mathrm{Sb}$ content in galena are below detection limit (Table 2).

Sphalerite forms skeletal intergrowths with galena and pyrite. It is iron-poor (less than $<0.71$ wt. \%) and contains minor $\mathrm{Cd}, \mathrm{Mn}$ and up to $0.3 \mathrm{wt} \%$ In (Table 2).

Tetrahedrite-freibergite solid solution is present in the form of up to $10 \mu \mathrm{m}$ inclusions in galena, usually associated with polybasite (Fig. 2d, f). High contents of Ag (up to 23.06 wt \%), are detected in the solid solution, substituting for $\mathrm{Cu}$, whereas $\mathrm{Pb}$ (up to $6.57 \mathrm{wt} \%$ ) and $\mathrm{Cd}$ (up to $5.39 \mathrm{wt} \%$ ) are substituting for $\mathrm{Zn}$ and Fe respectively (Table 1).

Polybasite accompanies Ag-bearing tetrahedrite in the mineralization. It occurs either as isolated grains in galena or rimming pyrite and Ag-rich tetrahedrite (Fig. $2 \mathrm{~d}$ to $\mathrm{f}$ ). The composition is almost matching with the ideal Sb-endmember, as indicated by the negligible As content (up to $0.30 \mathrm{wt} \%$ ), substituting for $\mathrm{Sb}$ in the structural formula (Table 2, Fig. 3).

\subsection{Geochemical study}

Selected bulk ore geochemical analyses from the Kondaros-Katsimoutis epithermal quartz-carbonate veins and breccias are presented in Table 3. Alfieris et al. (2013) identified a molybdenum geochemical anomaly (up to $176 \mathrm{mg} / \mathrm{kg}$ ) along two major NE trending lineaments, which also control the surface distribution of silicic- and advanced argillic alteration in northwestern Milos (Triades-Katimouti area). According to the above authors there is also a positive correlation between Mo and $\mathrm{W}$ geochemical anomalies.

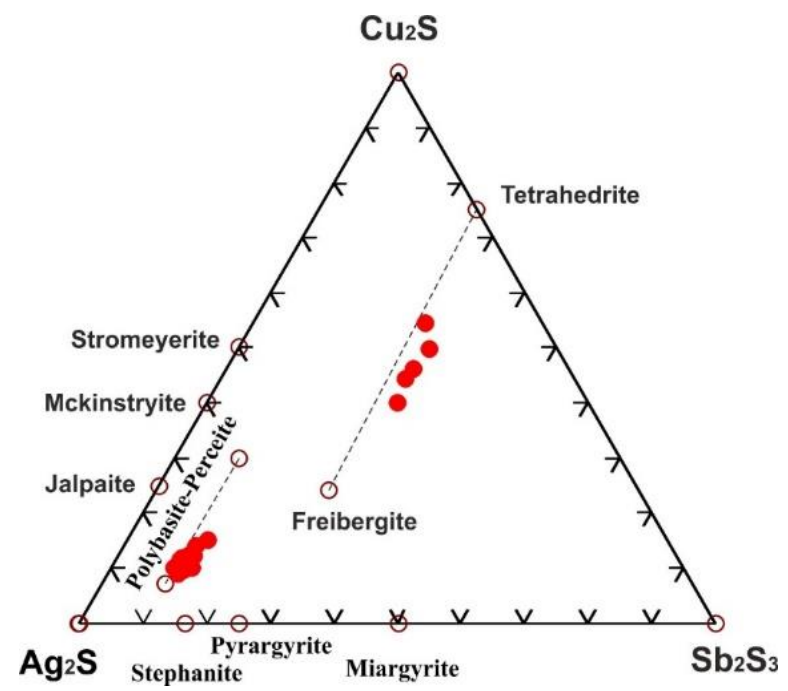

Figure 3 - Chemical composition of Ag-bearing sulfosalts from Kondaro and Katsimouti area in terms of the Ag-Cu-(Sb+As) ternary diagram (after Alfieris et al., 2013). Theoretical compositions are shown as open circles. Compositional ranges of tetrahedrite-freibergite and polybasite-pearceite solid solution are shown by dashed lines for reference. 
Table 2 - Representative microanalyses of galena (1), sphalerite (2-3), tetrahedrite (4-6) and polybasite (7-11) from Kondaros-Katsimouti, (values in \%, (-): not detected).

\begin{tabular}{|c|c|c|c|c|c|c|c|c|c|c|c|}
\hline & 1 & 2 & 3 & 4 & 5 & 6 & 7 & 8 & 9 & 10 & 11 \\
\hline $\mathbf{C u}$ & - & - & - & 18.13 & 22.19 & 24.87 & 4.55 & 6.09 & 5.23 & 5.81 & 6.22 \\
\hline Ag & - & - & - & 23.06 & 20.01 & 16.9 & 69.3 & 69.54 & 70.18 & 69.42 & 69.06 \\
\hline $\mathrm{Fe}$ & - & 0.29 & 0.11 & 1.50 & 1.44 & 1.17 & - & - & - & - & - \\
\hline Zn & - & $\begin{array}{c}65.9 \\
3\end{array}$ & $\begin{array}{c}65.4 \\
6\end{array}$ & 2.89 & 1.49 & 4.58 & - & - & - & - & - \\
\hline $\mathbf{S b}$ & - & & & 6.57 & 27.03 & 28.48 & 10.69 & 10.07 & 9.83 & 10.71 & 9.99 \\
\hline As & - & - & - & 0.04 & 0.14 & 0.24 & 0.10 & 0.22 & 0.06 & 0.14 & 0.30 \\
\hline Hg & - & - & - & - & - & - & - & - & - & - & - \\
\hline Cd & - & 0.69 & 0.91 & - & 5.39 & - & - & - & - & - & - \\
\hline $\mathbf{P b}$ & 87.17 & - & - & 6.57 & - & - & - & - & - & - & - \\
\hline Mn & - & - & - & - & - & - & - & - & - & - & - \\
\hline $\mathbf{S}$ & 13.46 & $\begin{array}{c}31.7 \\
6\end{array}$ & $\begin{array}{c}33.0 \\
6\end{array}$ & 20.57 & 21.82 & 23.47 & 14.6 & 14.94 & 16.02 & 15.27 & 14.51 \\
\hline $\mathbf{B i}$ & - & - & - & - & - & - & - & - & - & - & - \\
\hline In & - & 0.31 & - & - & - & - & - & - & - & - & - \\
\hline Total & $\begin{array}{c}100.6 \\
3\end{array}$ & $\begin{array}{c}98.9 \\
6\end{array}$ & $\begin{array}{c}99.3 \\
8\end{array}$ & 98.88 & 99.51 & 99.71 & 99.25 & $\begin{array}{c}100.8 \\
6\end{array}$ & $\begin{array}{c}101.3 \\
1\end{array}$ & $\begin{array}{c}101.3 \\
6\end{array}$ & $\begin{array}{c}100.0 \\
8\end{array}$ \\
\hline $\begin{array}{c}\text { Ato } \\
\text { ms }\end{array}$ & 2 & 2 & 2 & 29 & 29 & 29 & 29 & 29 & 29 & 29 & 29 \\
\hline $\mathrm{Cu}$ & 0.000 & $\begin{array}{c}0.00 \\
0\end{array}$ & $\begin{array}{c}0.00 \\
0\end{array}$ & 5.672 & 6.597 & 7.059 & 1.647 & 2.152 & 1.818 & 2.039 & 2.227 \\
\hline Ag & 0.000 & $\begin{array}{c}0.00 \\
0\end{array}$ & $\begin{array}{c}0.00 \\
0\end{array}$ & 4.248 & 3.503 & 2.825 & $\begin{array}{c}14.80 \\
1\end{array}$ & $\begin{array}{c}14.46 \\
8\end{array}$ & $\begin{array}{c}14.35 \\
8\end{array}$ & $\begin{array}{c}14.34 \\
6\end{array}$ & $\begin{array}{c}14.59 \\
1\end{array}$ \\
\hline $\mathbf{F e}$ & 0.000 & $\begin{array}{c}0.00 \\
3\end{array}$ & $\begin{array}{c}0.00 \\
2\end{array}$ & 0.534 & 0.487 & 0.38 & 0.000 & 0.000 & 0.000 & 0.000 & 0.000 \\
\hline $\mathbf{Z n}$ & 0.000 & $\begin{array}{c}1.00 \\
2\end{array}$ & 0.98 & 0.879 & 0.432 & 1.261 & 0.000 & 0.000 & 0.000 & 0.000 & 0.000 \\
\hline Sb & 0.000 & $\begin{array}{c}0.00 \\
0\end{array}$ & $\begin{array}{c}0.00 \\
0\end{array}$ & 4.266 & 4.190 & 4.217 & 2.024 & 1.856 & 1.78 & 1.96 & 1.865 \\
\hline As & 0.000 & $\begin{array}{c}0.00 \\
0\end{array}$ & $\begin{array}{c}0.00 \\
0\end{array}$ & 0.011 & 0.035 & 0.058 & $\begin{array}{c}0 . .03 \\
2\end{array}$ & 0.064 & 0.017 & 0.04 & 0.087 \\
\hline Hg & 0.000 & $\begin{array}{c}0.00 \\
0\end{array}$ & $\begin{array}{c}0.00 \\
0\end{array}$ & 0.000 & 0.000 & 0.000 & 0.000 & 0.000 & 0.000 & 0.000 & 0.000 \\
\hline Cd & 0.000 & $\begin{array}{c}0.00 \\
6\end{array}$ & $\begin{array}{c}0.00 \\
8\end{array}$ & 0.000 & 0.905 & 0.000 & 0.000 & 0.000 & 0.000 & 0.000 & 0.000 \\
\hline $\mathbf{P b}$ & 1.001 & $\begin{array}{c}0.00 \\
0\end{array}$ & $\begin{array}{c}0.00 \\
0\end{array}$ & 0.629 & 0.000 & 0.000 & 0.000 & 0.000 & 0.000 & 0.000 & 0.000 \\
\hline Mn & 0.000 & $\begin{array}{c}0.00 \\
0\end{array}$ & $\begin{array}{c}0.00 \\
0\end{array}$ & 0.000 & 0.000 & 0.000 & 0.000 & 0.000 & 0.000 & 0.000 & 0.000 \\
\hline $\mathbf{S}$ & 0.500 & $\begin{array}{c}0.98 \\
4\end{array}$ & $\begin{array}{c}1.09 \\
5\end{array}$ & $\begin{array}{c}12.75 \\
7\end{array}$ & $\begin{array}{c}12.84 \\
7\end{array}$ & $\begin{array}{c}13.19 \\
8\end{array}$ & $\begin{array}{c}10.49 \\
5\end{array}$ & $\begin{array}{c}10.45 \\
7\end{array}$ & $\begin{array}{c}11.02 \\
6\end{array}$ & $\begin{array}{c}10.61 \\
1\end{array}$ & 10.28 \\
\hline $\mathbf{B i}$ & 0.000 & $\begin{array}{c}0.00 \\
0\end{array}$ & $\begin{array}{c}0.00 \\
0\end{array}$ & 0.000 & 0.000 & 0.000 & 0.000 & 0.000 & 0.000 & 0.000 & 0.000 \\
\hline In & 0.000 & $\begin{array}{c}0.00 \\
3\end{array}$ & $\begin{array}{c}0.00 \\
0\end{array}$ & 0.000 & 0.000 & 0.000 & 0.000 & 0.000 & 0.000 & 0.000 & 0.000 \\
\hline
\end{tabular}


This study demonstrates Mo- and tungsten-enrichment (up to $24 \mathrm{mg} / \mathrm{kg}$ and $424 \mathrm{mg} / \mathrm{kg}$ respectively) along the NW-trending Kondaros-Katsimouti fault. The studied samples are also highly enriched in $\mathrm{Pb}$ and $\mathrm{Zn}$ with concentrations of up to $31.8 \mathrm{wt} \%$ and $16.5 \mathrm{wt} \%$ respectively. The presence of $\mathrm{Cd}$ in the structural formula of low-Fe sphalerite and Cd-Ag-rich tetrahedrite (Table 2) is reasonable for the elevated Cd concentrations in the bulk geochemical analyses (Kondaros: up to $247 \mathrm{mg} / \mathrm{kg} \mathrm{Cd}$; Katsimouti: up to $769 \mathrm{mg} / \mathrm{kg} \mathrm{Cd}$, Table 3). Similarly, the presence of Sb-bearing sulfosalts with minor As-content are responsible for the relevant concentrations in the bulk geochemical analyses (Kondaros: up to $243 \mathrm{mg} / \mathrm{kg} \mathrm{Sb}$ and up to $36 \mathrm{mg} / \mathrm{kg}$ As; Katsimouti: up to $178 \mathrm{mg} / \mathrm{kg} \mathrm{Sb}$ and up to $42 \mathrm{mg} / \mathrm{kg} \mathrm{As}$, Table 3). Bi, up to $1 \mathrm{mg} / \mathrm{kg}$, may indicate the presence of minor Bi-sulfosalts in the mineralization.

\section{Discussion and conclusions}

The western Milos ore deposits have been formed under transitional shallow submarine to subaerial conditions (Alfieris et al., 2013; Naden et al., 2005). Alfieris et al. (2013) and Voudouris et al. (2014) listed a number of mineralogical characteristics, which strongly support sub-seafloor deposition for the base- and precious metal mineralization along the NW-trending KondarosKatsimouti-Vani fault. Our mineralogical data (e.g. presence of adularia, hematite associated with sulfides, and amethystine quartz) verify previous work of Alfieris et al. (2013), and suggest boiling and fluctuating oxidizing-reducing conditions for the formation of the Kondaros-Katsimouti metallic mineral assemblage. Amethyst requires oxidizing conditions to obtain its colour, and this may be resulted by either mixing of oxidized meteoric and/or seawaters with upwelling hydrothermal fluids or boiling processes (Fournier, 1985). It is considered that the deposition of the metallic mineral phases at Kondaros-Katsimouti took place due to increasing $\mathrm{pH}$ and oxidation (as a result of boiling and mixing of fluids, respectively) and by temperature decrease from above $300^{\circ}$ to below $200{ }^{\circ} \mathrm{C}$ (Alfieris, 2006; Alfieris et al., 2013). These temperatures were estimated using the geothermometer of coexisting polybasite-pearceite and tetrahedrite-group minerals in the presence of sphalerite (Sack 2005). The lowest temperatures $\left(<180^{\circ} \mathrm{C}\right)$ predicted for coexisting sulfosalts in Kondaros-Katsimoutis could represent equilibration temperatures after cooling. Polybasite and argentian tetrahedrite-freibergite are the main silver minerals at Kondaros-Katsimoutis mineralization, and most probably they represent exsolved grains from a galena solid solution (Alfieris et al., 2013).

The metallic mineralization in Kondaros-Katsimouti area is highly enriched in W (up to $439 \mathrm{mg} / \mathrm{kg}$ ) and in lesser amounts of Mo (e.g. $24 \mathrm{mg} / \mathrm{kg}$ ), in common to other mineralization in northwestern Milos. Already Glasby et al. (2005) reported extremely high-enrichment (up to $2870 \mathrm{mg} / \mathrm{kg} \mathrm{W}$ ) for the Vani exhalative/inhalative manganese deposit and Alfieris et al. (2013) reported on a tungsten anomaly (up to $677 \mathrm{mg} / \mathrm{kg}$ ) related to Mo anomaly along the NE-trending Triades-Katsimoutis lineament.

They considered elevated contents of Mo and W at Triades-Galana-Kondaros, to be related to a buried granite at depth that fed volatiles and metals into the magmatic-hydrothermal system, consistent to Mo-enrichment in VMS deposits (Mercier-Langevin et al., 2011). Although exhalative processes are considered previously to be genetically connected to the transport of B and W and to the formation of syngenetic/syndiagenetic tungsten mineralization (Raith, 1988; Spry et al., 2000), new in-situ U-Pb age data confirm formation of tungsten mineralization from magmatichydrothermal fluids during granitoid emplacement (Raith, 2013).

Mineralization at Kondaros-Katsimouti resembles other intermediate-sulfidation mineralizations elsewhere, as for example Tonopah Ag-Zn-Pb deposit, Nevada (Sillitoe and Hedenquist, 2003), as well as epithermal deposits in Baia Mare polymetallic district, where tungsten in the form of wolframite and scheelite occurs in early stages of ore deposition associated with Fe-oxides (Grancea et al., 2002). Towards Vani, and at higher leves, the Kondaros-Kastimouti ore system becomes more Ag-rich (eg. Vani Ag-Pb deposits; Voudouris et al., 2014), probably as a result of combined action of increasing mixing- (between magmatic and seawater) and boiling processes. 
Table 3 - Representative bulk ore geochemical analyses from Kondaros-Katsimouti.

\begin{tabular}{cccccccccc}
\hline & & KA- & KA- & KA- & KA- & KA- & KA- & KO- & KO- \\
& & $\mathbf{1 A}$ & $\mathbf{1 B}$ & $\mathbf{2}$ & $\mathbf{3}$ & $\mathbf{4}$ & $\mathbf{4 Q}$ & $\mathbf{1}$ & $\mathbf{2}$ \\
\hline $\mathbf{N a 2}$ & $\%$ & 0.17 & 0.05 & 0.08 & 0.81 & 0.17 & 0.06 & 0.05 & 0.03 \\
$\mathbf{K} 2 \mathbf{O}$ & $\%$ & 0.31 & 0.06 & 0.24 & 0.16 & 0.14 & 0.09 & 0.06 & 0.03 \\
$\mathbf{M g O}$ & $\%$ & 0.25 & 0.46 & 0.17 & 0.53 & 0.03 & 0.02 & 0.16 & 0.01 \\
$\mathbf{C a O}$ & $\%$ & 15.24 & 47.54 & 13.39 & 45.61 & 0.03 & 0.03 & 3.67 & 0.12 \\
$\mathbf{A l}_{2} \mathbf{O}_{3}$ & $\%$ & 0.65 & 0.10 & 0.62 & 0.08 & 0.61 & 0.44 & 0.23 & 0.11 \\
$\mathbf{T i O}$ & $\%$ & 0.01 & bdl & 0.01 & bdl & bdl & bdl & bdl & bdl \\
$\mathbf{M n O}$ & $\%$ & 0.99 & 8.32 & 0.73 & 10.15 & 0.06 & 0.03 & 0.73 & 0.04 \\
$\mathbf{F e} \mathbf{O}_{3}$ & $\%$ & 1.82 & 1.86 & 2.97 & 1.56 & 1.15 & 1.73 & 2.13 & 0.11 \\
$\mathbf{Z n}$ & $\%$ & 16.5 & 0.15 & 14.2 & 0.12 & 8.17 & 4.38 & 6.70 & 1.52 \\
$\mathbf{P b}$ & $\%$ & 2.65 & 0.03 & 2.83 & 0.05 & 29.8 & 0.75 & 21.8 & 0.36 \\
$\mathbf{C u}$ & $\%$ & 0.04 & 0.002 & 0.05 & 0.002 & 0.08 & 0.03 & 0.03 & 0.002 \\
$\mathbf{B a}$ & $\%$ & 0.01 & 0.003 & 0.01 & 0.02 & 0.002 & 0.001 & 0.001 & 0.21 \\
$\mathbf{A s}$ & $\mathrm{mg} / \mathrm{kg}$ & 14 & 4 & 42 & 4 & 8 & 18 & 36 & 1 \\
$\mathbf{S b}$ & $\mathrm{mg} / \mathrm{kg}$ & 68 & 1 & 42 & 0 & 178 & 94 & 243 & 46 \\
$\mathbf{N i}$ & $\mathrm{mg} / \mathrm{kg}$ & 22 & 16 & 24 & 16 & 26 & 27 & 26 & 27 \\
$\mathbf{C o}$ & $\mathrm{mg} / \mathrm{kg}$ & 31 & 30 & 42 & 18 & 22 & 98 & 20 & 123 \\
$\mathbf{W}$ & $\mathrm{mg} / \mathrm{kg}$ & 49 & 26 & 159 & bdl & 94 & 439 & 2 & 424 \\
$\mathbf{C d}$ & $\mathrm{mg} / \mathrm{kg}$ & 769 & 7 & 622 & 3 & 410 & 207 & 247 & 86 \\
$\mathbf{M o}$ & $\mathrm{mg} / \mathrm{kg}$ & 23 & 4 & 24 & 4 & 10 & 5 & 9 & 2 \\
$\mathbf{T l}$ & $\mathrm{mg} / \mathrm{kg}$ & 0.26 & 0.30 & 0.26 & 0.10 & 0.54 & 0.05 & 0.62 & 0.01 \\
$\mathbf{B i}$ & $\mathrm{mg} / \mathrm{kg}$ & 0.03 & $\mathrm{bdl}$ & 0.05 & bdl & 0.26 & 0.01 & 1.05 & $\mathrm{bdl}$ \\
\hline bdl: below detection limit. & & & & & & & \\
& & & & & & & & &
\end{tabular}

\section{References}

Alfieris, D., 2006. Geological, geochemical and mineralogical studies of shallow submarine epithermal mineralization in an emergent volcanic edifice, at western Milos island, Greece. $\mathrm{PhD}$ thesis, University of Hamburg, Germany, $211 \mathrm{pp}$.

Alfieris, D. and Voudouris, P., 2005. Ore mineralogy of transitional submarine to subaerial magmatic-hydrothermal deposits in W. Milos, Greece. In: Cook, N.G. and Bonev, I., eds., Au-Ag-Te-Se deposits, Geochemistry, Mineralogy and Petrology, 43, Sofia, 1-6.

Alfieris, D., Voudouris, P. and Spry, P.G., 2013. Shallow submarine epithermal Pb-Zn-Cu-Au-AgTe mineralization on western Milos Island, Aegean Volcanic Arc, Greece: Mineralogical, Geological and Geochemical constraints, Ore Geology Reviews, 53, 159-180.

Altherr, R. and Siebel, W., 2002. I-type plutonism in a continental back-arc setting: Miocene granitoids and monzonites from the central Aegean Sea, Greece, Contrib. Mineral. Petrol., 143, 397-415.

Fournier, R.O., 1985. The behaviour of silica in hydrothermal solutions, In: Berger, B.R. and Bethke, P.M., eds., Geology and geochemistry of epithermal systems, Rev. Econ. Geol., 2, 45-61.

Fytikas, M., Innocenti, F., Kolios, N., Manneti, P., Mazzuoli, R., Poli, G., Rita, F. and Villari, L., 1986. Volcanology and petrology of volcanic products from the island of Milos and neighbouring islets, J. Volcanol. Geotherm. Res., 28, 297-317. 
Glasby, G.P., Papavassiliou, C.T., Mitsis, J., Valsami-Jones, E., Liakopoulos, A. and Renner, R.M., 2005. The Vani manganese deposit, Milos island, Greece: a fossil stratabound $\mathrm{Mn}-\mathrm{Ba}-\mathrm{Pb}-$ Zn-As-Sb-W-rich hydrothermal deposit. In: Fytikas, M. and Vougioukalakis, G.E., eds., The South Aegean Active Volcanic Arc: Present Knowledge and Future Perspectives. Developments in Volcanology, 7. Elsevier, 255-291.

Grancea, L., Bailly, L., Leroy, J., Banks, D., Marcoux, E., Milési, J.P., Cuney, M., André, A.S., Istvan, D. and Fabre, C., 2002. Fluid evolution in the Baia Mare epithermal gold /polymetallic district, Inner Carpathians, Romania, Mineral. Deposita, 37, 630-647.

Hauck, M., 1988. Kuroko-type ore deposits on the Aegean Islands, Greece. In: Friedrich, G.M. and Herzig, P.M., eds., Base metal sulfide deposits. Springer Verlag, Berlin, 216-228.

Hein, J.R., Stamatakis, M.G. and Dowling, J.S., 2000. Trace metal-rich Quaternary hydrothermal manganese oxide and barite deposit, Milos Island, Greece, Trans Inst Min Metall, 109, 67-76.

Jolivet, L. and Brun, J.P., 2010. Cenozoic geodynamic evolution of the Aegean region, Int. J. Earth Sci., 99, 109-138.

Kilias, S.P., Naden, J., Cheliotis, I., Shepherd, T.J., Constandinidou, H., Crossing, J. and Simos, I., 2001. Epithermal gold mineralisation in the active Aegean volcanic arc: The Profitis Ilias deposit, Milos Island, Greece, Miner. Deposita, 36, 32-44.

Kilias, S.P., Nomikou, P., Papanikolaou, D., Polymenakou, P.N., Godelitsas, A., Argyraki, A., Carey, S., Gamaletsos, P., Mertzimekis, T.J., Stathopoulou, E. and Goettlicher, J., 2013. New insights into hydrothermal vent processes in the unique shallow-submarine arc-volcano, Kolumbo (Santorini), Greece, Scientific Reports, 3, 2421, 1-13.

Liakopoulos, A, Glasby, G.P., Papavassiliou, C.T. and Boulegue, J., 2001. Nature and origin of the Vani manganese deposit, Milos, Greece: an overview, Ore Geol. Rev., 18, 181-209.

Marschik, R., Bauer, T., Hensler, A.S., Skarpelis, N. and Holzl, S., 2010. Isotope Geochemistry of the Pb-Zn$\mathrm{Ba}(-\mathrm{Ag}-\mathrm{Au})$ Mineralization at Triades-Galana, Milos Island, Greece, Res. Geology, 60, 335-347.

Mercier-Langevin, P., Hannington, M.D., Dubé, B. and Bécu, V., 2011. The gold content of volcanogenic massive sulfide deposits, Miner. Deposita, 46, 509-539.

Naden, J., Kilias, S.P. and Darbyshire, D.B.F., 2005. Active geothermal systems with entrained seawater as analogues for transitional continental magmato-hydrothermal and volcanic-hosted massive sulfide mineralization-the example of Milos Island, Greece, Geology, 33, 541-544.

Papanikolaou, D.J., 1987. Tectonic evolution of the Cycladic blueschist belt (Aegean Sea, Greece). In: Helgeson, H.C., ed., Chemical transport in metasomatic processes: NATO ASI series, 218, 429-450.

Raith, J.G., 1988. Tourmaline rocks associated with stratabound scheelite mineralization in the Austroalpine crystalline complex, Austria, Mineral. Petrol., 39, 265-288.

Raith, J.G., 2013. Stratabound tungsten deposits in the Alps revisited in the light of new age data, Geophysical Research Abstracts, Vol. 15, EGU2013-5095, 2013 EGU General Assembly.

Ring, U., Glodny, J., Will, T. and Thomson, S., 2010. The Hellenic subduction system: high pressure metamorphism, exhumation, normal faulting, and large-scale extension, Ann. Rev. Earth Planet. Sci., 38, 45-76.

Sack, R.O., 2005. Internally consistent database for sulfides and sulfosalts in the system $\mathrm{Ag}_{2} \mathrm{~S}-\mathrm{Cu}_{2} \mathrm{~S}-$ $\mathrm{ZnS}-\mathrm{FeS}-\mathrm{Sb}_{2} \mathrm{~S}_{3}-\mathrm{As}_{2} \mathrm{~S}_{3}$ : Update, Geoch. Cosmoch. Acta, 69, 1157-1164.

Sillitoe, R.H. and Hedenquist, J.W., 2003. Linkages between volcanotectonic settings, ore-fluid compositions, and epithermal precious-metal deposits, Soc. Econ. Geol., Special Publ., 10, 315-343.

Spry, P.G., Peter, J.M. and Slack, J.M. 2000. Metaexalites as exploration guides to ores, Rev. Econ. Geol., 11, 163-201.

Stewart, A.L. and McPhie, J., 2006. Facies architecture and Late Pliocene-Pleistocene evolution of a felsic volcanic island, Milos, Greece, Bull. Volcanol., 68, 703-726.

Vavelidis, M. and Melfos, V., 1997. Two plumbian tetrahedrite-tennantite occurrences from Maronia area (Thrace) and Milos island (Aegean Sea, Greece), Eur. J. Mineral., 9, 653-657.

Vavelidis, M. and Melfos, V., 1998. Fluid inclusion evidence for the origin of the barite silver-gold-bearing PbZn mineralization of the Triades area, Milos Island, Greece, Bull. Geol. Soc. Greece, 32, 137-144.

Voudouris, P., Xydous, S., Alfieris, D., Veligrakis, Th., Papavasiliou, C., Kanellopoulos, C. and Falalakis, G., 2014. Silver-rich sulfide mineralization at Vani, western Milos Island, Greece: New mineralogical evidence for epithermal ore deposition in a shallow submarine environment, Proceedings of XX CBGA Congress, Tirana, Albania. Bul. Shk. Gjeol., 1/2014, 187-190. 